\title{
Total Quality Management for New Product Design and Implementing of QFD
}

\author{
Semih Dönmezer \\ Marketing and Advertising Department \\ Vocation High School \\ Anadolu University, 26470 \\ Turkey
}

\begin{abstract}
New product design option presents in some of compact way, namely, how did you choose which design parameters are important, which parts did you eliminate easily, and so if all that can be introduction on the design problem. QFD is a flexible and comprehensive Decision-making technique which is used in product or service development brand marketing, and product management. QFD is a structured approach defining to customer needs or requirements and translating into specific plans to produce to meet those needs. Many successful organizations collect and integrate the Voice of the Customer (VOC) into the design and manufacture of their products. Many companies use a structured process to define the needs and desires of their customers and transform them into specific product designs and process plans to produce products that meet the needs of the customer. The process or tool that is called Quality Function Deployment ( $Q F D)$.
\end{abstract}

Keywords: Matrix product planning, decision metrics, customer driven engineering, Voice of the Customer.

\section{Introduction}

DFA method and the design process are an iterative, complex, decision-making engineering activity that leads to detailed drawings by which manufacturing can economically produce a quantity of identical products that can be sold. The design process usually starts with the identification of a need, proceeds through a sequence of activities to seek an optimal solution to the problem, and ends with a detailed description of the product. Design for assembly (DFA) should be considered at all stages of the design process. As the design team conceptualizes alternative solutions and begins to realize their thoughts on paper, it should give serious consideration to the ease of assembly of the product or subassembly during production and during field service. As part of the detail design of parts and assemblies, part features, dimensions, and tolerances should be checked to make certain that they reflect the findings and conclusions of the DFA analysis. Design engineers need a DFA tool to analyze effectively the ease of assembly of the products or subassemblies they design. The design tool should provide quick results and be simple and easy to use. By applying a DFA tool, communication between manufacturing and design engineering is improved, and ideas, reasoning, and decisions made during the design process become well documented for future reference. The DFA method attempts to meet these objectives by:

1. Minimizing the dependence of the design engineer on the support of the manufacturing engineer by providing much of the assembly information needed to design new products for "ease of assembly."

2. Guiding the designer to simplify the product so that savings in both assembly costs and piece-parts costs can be realized.

3. Gathering information normally possessed by the experienced design engineer and arranging it, in a convenient way, for use by less experienced designers.

4. Establishing a data base that consists of assembly times and cost factors for various design situations and production conditions ${ }^{\mathrm{i}}$.

\section{Literature Review of QFD}

Quality function deployment (QFD) is a technique which was born in Japan as a strategy for assuring that quality is built into new products. QFD was first used in 1972 by Kobe Shipyard of Mitsubishi Heavy Industries Ltd and was then referred to as the quality tables. While the use of QFD in Japan hasincreased over the years, its extension to the West was, however, very slow. The first examples of using QFD in the USA did not emerge until 1986 when companies such as Ford and Rank Xerox first introduced it. Subsequently other companies started to introduce it, for example: AT\&T Bell Labs, Digital Equipment, Procter \& Gamble and Hewlett-Packard. In the UK the uptake of QFD is very recent and there are only a few scattered cases of companies trying to experiment with it ${ }^{\mathrm{ii}}$. 
TQM has been used successfully in a variety of organizations, including manufacturing and service companies, health care organizations, government agencies and many others (Glenn, 1991; Labovitz, 1991; Marchese, 1992; Zentmyer and Zimble, 1991). The statistical control techniques advocated byEdward Deming (1986), have been widely used to improve quality in manufacturing and service companies. Although application of TQM in higher education institutions started later than in industries, gradually colleges and universities are adopting TQM principles. Some researchers have documented the experience of TQM implementation in some institutions of higher education.

TQM has been used successfully in a variety of organizations, including manufacturing and service companies, health care organizations, government agencies and many others (Glenn, 1991; Labovitz, 1991; Marchese, 1992; Zentmyer and Zimble, 1991). The statistical control techniques advocated by Edward Deming (1986), have been widely used to improve quality in manufacturing and service companies. Although application of TQM in higher education institutions started later than in industries, gradually colleges and universities are adopting TQM principles. Some researchers have documented the experience of TQM implementation in some institutions of higher education ${ }^{\text {iii }}$

Quality function deployment (QFD) originated in Mitsubishi's Kobe shipyard in 1972, possibly as an outcome of Deming's teachings. The original Japanese name was hin shitsu ki no ten kai. The translation is given below:

- hin shitsu means quality or features/attributes; -

- ki no means function or mechanization;

- ten kai means deployment, diffusion, or development/evolution ${ }^{\text {iv }}$

\section{Using of $Q F D$}

When the Taunus/Sable programmed was developed, Ford Motor Company discovered that QFD was an excellent method to help design and launch a product ${ }^{\mathrm{V}}$. Since 1987, Ford has been a leader in the use of QFD. As of January 1991, more than 5,000 Ford employees had received QFD training, which suggests Ford's view of the importance of this process ${ }^{\mathrm{vi}}$. Cadillac's culture shift to an environment that included QFD led to the Malcolm Baldrige National Quality Award in $1990^{\text {vii }}$. Chrysler Corporation used QFD in its recently introduced LH platform ${ }^{\text {viii }}$. Dodge Group of Reliance Electric (DGRE), a bearing manufacturer in Greenville, South Carolina, employed QFD in the re-design of a SAF mounted spherical roller beating, a type found on conveyors, fans, and countless other machines. DGRE was able to produce a single design - a Unifies SAF - that would do the job of its two existing noninterchangeable versions. They used QFD to help satisfy customer wants and complaints aboutcompeting products ${ }^{\mathrm{ix}}$. Toyota and NGK (by using QFD) reported the following benefits: engineering changes were cut by 30 to 50 per cent, design cycles were shortened by 30 to 50 per cent, start-up costs were trimmed by 20 to 60 per cent, and warranty claims were reduced by 20 to 50 per cent. Toyota has also improved its rust prevention record from one of the average in the world to one of the best ${ }^{\mathrm{x}}$.

\section{Opportunity Analysis}

Often there are a large number of possible customer outcome and market segment combinations, but it is impossible to successfully address all of these areas at the same time. There is a need to focus on the few vital opportunity areas, otherwise across-the-board funding results in important areas being under-resourced while other areas consume too many resources. Opportunity analysis focuses attention on the handful of opportunities that will maximize the leverage from the limited resources available. These key opportunity areas are identified by desired customer outcomes that are both highly important and poorly satisfied. The "opportunity algorithm" is a simple yet effective heuristic measure that combines these two aspects in a single metric (Ulwick, 2002b).

\section{Opportunity. Importance + (Importance + Satisfaction $)$}

The opportunity algorithm data is also used in the market segmentation to focus the clustering analysis on the small number of natural segments that can generate and overall opportunities from the relatively large initial set of outcomes $^{\mathrm{xi}}$.

A major problem in the United States electronics industry has been a product design dominated by product designers rather than by customers. Now, companies such as Digital Equipment Corporation and Hewlett Packard are using QFD to get more customer input into the product design process ${ }^{\mathrm{xii}}$. Managers are needed who understand the potential of technology, and scientists and engineers are needed who understand management's constraints. QFD helps to make these situations a reality ${ }^{\text {xiii }}$. 


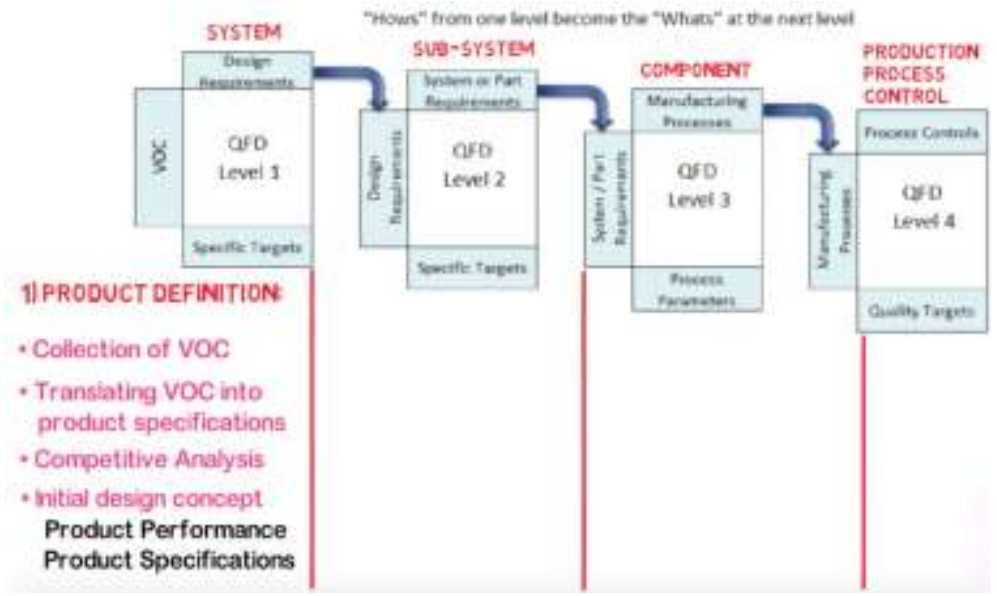

Figure 1. How to implement QFD

\section{How Does QFD Work?}

QFD has three objectives that's are, to identify the customer, to identify what the customer wants and how to fulfil our customer's wants ${ }^{\mathrm{xiv}}$.

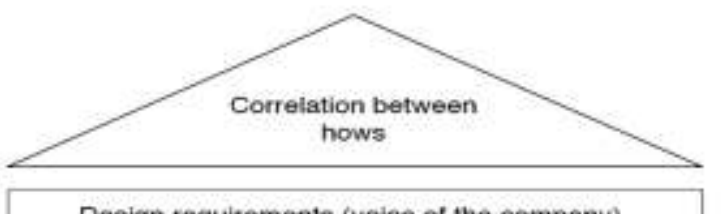

Design requirements (voice of the company) Hows
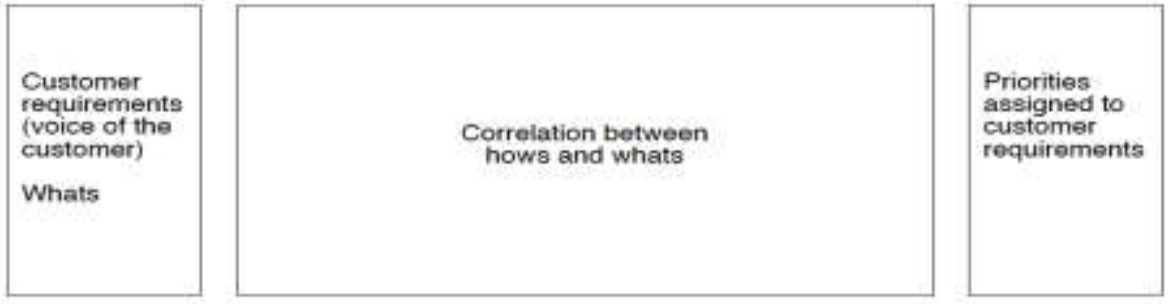

Priorities assigned to design requirements

Figure 2. Basic concepts of QFD

\section{The Benefits of Customers}

QFD instigates discipline throughout the various activities of the business delivery system. First of all, it ensures that the starting point is listing customer requirements then translating the latter into physical and measurable outputs, then it examines the parts required, the process capability and the productioncapability.Besides its power as a benchmarking tool, QFD offers a wide variety ofbenefits including the following:

- It takes the customer as a starting point.

- It cuts down on cycle time since it encourages designing right first timeby closely sticking to customers' true requirements.

- It is a tool for never-ending improvement. If offers the ability to prioritizecustomers' own preferences and following a ranking procedure, suppliers may not necessarily have to focus on customers' top prioritiesif these are strong enough on other aspects which they may be weak at.

- It is a team building process. QFD forms teams by encouraging input notjust from marketing, development, manufacturing and distribution. Itcombines efforts which link in the emotional needs of customers to those which have to convert them into physical outputs which are producedand delivered to the satisfaction of the end customer.

- QFD helps create a strong database of customer understanding andinternal effectiveness and external competitiveness. 
- QFD provides firms with the opportunity to reduce costs and waste byusing experiential learning and constantly working on reducing cycletime for product to market.

- QFD is a tool of innovation since it currently encourages people to ratetheir capabilities against those of competitors and others. It assesses theability of the process to deliver the customer right first time and everytime ${ }^{\mathrm{xv}}$.

\section{Problems with QFD Implementation}

There are however various reported problems with the use of QFD. Ernst \& Young ${ }^{\text {xvi }}$ identified the following problems associated with QFD implementation: Engineers think that QFD is a "false science", too focused on the mechanics of scoring. QFD however is an effective tool of capturing and displaying data and serves as a communication vehicle for generating structured discussions among team members, in order to meet customer requirements and it can take long time development ${ }^{\text {xvii }}$.

\section{Vehicle Development ${ }^{\text {rvii }}$}

The implementation and success of QFD depends on many prerequisites or critical factors, the firstof which is support for QFD from top management. In order to be competitive in this global market, top management of an organization should demonstrate support for this new approach. For example, at Ford, top management has embraced the Ford total quality excellence philosophy ${ }^{\text {xix }}$. The job of top management should include: making it clear that QFD is a priority; setting clear priorities for QFD activities; insisting that design be based on customer requirements; and becoming leaders of QFDrather than managers ${ }^{\mathrm{xx}}$.

When the strategic and operational goals for a business line are defined, they must be broken down to the individual products. For complex products with a large number of assemblies, several system suppliers and extensive production facilities, the most precise description possible of the product requirements became major importance. In the development of Vehicles, various specialist departments and suppliers for the duration of the project are interconnected via many interfaces. Only if these interfaces are clearly defined, it can be sensibly assembled the later complex end product from its many manageable subsystems. These subsystems may include concrete components as parts, assemblies and modules, or development scopes as a design scope, simulation, testing.Requirements, concise and precise formulation of a desired feature. By defining and assembling requirement lists, four goals are to be pursued.

1. Collect all relevant data at the beginning of the development process

2. Systematic processing of collected product and market data

3. Basis for later assessment of proposed solutions and variants.

4. Binding contract basis for client and contractor.

The composition of these requirements has different meanings depending on the function and time in the development process. Normally a distinction is made between specifications, specifications and requirements list. The requirements specification describes the requirements and the product from the customer's point of view. The features are often still crude and not directly usable by the supplier or the developing department. Based on this, the contractor, the supplier of the specialist department, draws up a specification sheet. This contains the load of the customer but also a much more detailed list of all requirements from a design perspective.

Development contract are given in addition to the technical requirements further marginal conditions.

- Costs, total R \& D costs, staff costs, costs for each type and subcontractor.

- Expenditure, total effort and R \& D hours in development / design, workshop, laboratory and fixture construction

- Profit, Forecasted Sales, Planned Stocks and Profit Margins

- Organization, approving posts, hierarchical and functional incorporation, reporting, milestones. 


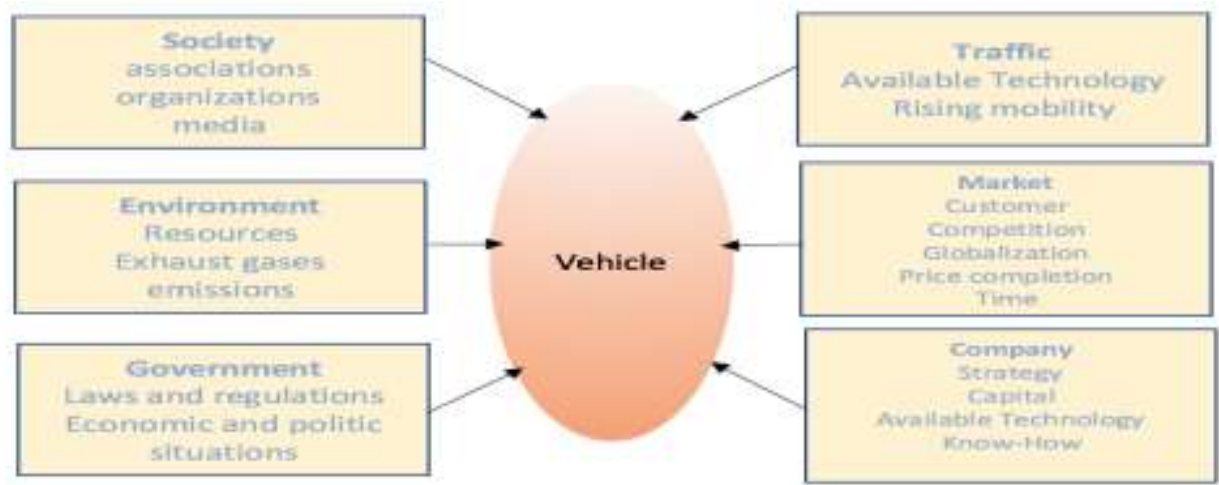

Figure 3. Requirements for a vehicle concept

\section{Create Requirement Lists}

The creation of the requirement lists is a process that cover the entire product duration. In the first stages of product development, a rough vehicle concept is first created. Here the influences from society, environment, markets, state, traffic and enterprise for the entire vehicle level are described. The requirements are defined in a four-step process, which is repeated several times in iterative loops by constantly concretizing the product characteristics and updating the framework conditions.

\begin{tabular}{|c|c|}
\hline Main Feature & Examples \\
\hline Function & Overall function / main function, sub-function, secondary function \\
\hline geometry & $\begin{array}{l}\text { Size, height, width, length, diameter, number, arrangement, } \\
\text { connection and extension }\end{array}$ \\
\hline kinematics & Movement type, direction of movement, speed, acceleration \\
\hline Power-force & $\begin{array}{l}\text { Force size, direction of force, force frequency, weight, load, } \\
\text { deformation, spring characteristics, stability, resonances, }\end{array}$ \\
\hline Energy & $\begin{array}{l}\text { Power, efficiency, loss, friction, ventilation, state quantity such as } \\
\text { pressure, temperature, }\end{array}$ \\
\hline Material & $\begin{array}{l}\text { Physical and chemical properties of the input, and initial policy, } \\
\text { auxiliary substances, prescribed materials (food law), material flow } \\
\text { and transport }\end{array}$ \\
\hline Signal & $\begin{array}{l}\text { Input and output signals, display mode, operation and monitoring } \\
\text { devices, waveform }\end{array}$ \\
\hline security & $\begin{array}{l}\text { Immediate safety engineering, protection systems, operation, } \\
\text { labour, and environmental safety }\end{array}$ \\
\hline ergonomics & $\begin{array}{l}\text { Human to machine relationship, conditions, type of condition, } \\
\text { clarity, lighting, shape design }\end{array}$ \\
\hline production & $\begin{array}{l}\text { Restricted by production location, preferred manufacturing process, } \\
\text { production equipment, quality, tolerances }\end{array}$ \\
\hline control & $\begin{array}{l}\text { Measuring and testing facilities, special regulations (DIN-ISO-AD-, } \\
\text { Crash-Methods) }\end{array}$ \\
\hline Assembly & $\begin{array}{l}\text { Special assembly regulations, assembly, installation, site assembly, } \\
\text { foundation }\end{array}$ \\
\hline Transport & $\begin{array}{l}\text { Limitation by hoists, track profile, transport routes by size and } \\
\text { weight, shipping method and conditions }\end{array}$ \\
\hline use & $\begin{array}{l}\text { Low noise, Waste rate, application and sales area, location, } \\
\text { (difficult atmosphere, tropics .) }\end{array}$ \\
\hline maintenance & $\begin{array}{l}\text { Maintenance-free or number of time requirements for maintenance, } \\
\text { inspection, replacement and repair. }\end{array}$ \\
\hline Recycling & Reuse, again valuation, disposal \\
\hline costs & $\begin{array}{l}\text { Max. Permissible production costs, tool costs, investment and } \\
\text { amortization, }\end{array}$ \\
\hline Appointment & End of development, network for intermediate steps, delivery time \\
\hline
\end{tabular}

Table I. Check list for setting up requirements ${ }^{\mathrm{xxi}}$ 


\section{Demands for the realization process}

In a first phase, the requirements must first be collected. For this, all relevant areas must be systematically considered. In addition to the actual technical requirements, these are also a series of additional framework conditions and quality features.

- Legal and regulatory requirements

- Standards and guidelines

- Application and use conditions

- Reliability requirements

The goal for the selection of requirements should be the principle "as much as necessary" "as little as possible". No significant aspect should be left out, since the subsequent change of the construction is associated with high additional costs. Likewise, having to overload the requirement lists with unimportant and redundant information must be avoided. Basically, only the required production characteristics should be mentioned in the requirements, but the solution principle should not be stipulated. This gives the contractor greater latitude for possibly new approaches to solutions. Three rules;

1. Capture all relevant requirements, but exactly these too

2. Specify requirements clearly with quantitative technical data

3. Formulate production characteristics as solution-neutral as possible.

Requirements with many hundred individual features necessary. In order to avoid overlaps and to ensure the later weighing any conflicting characteristics.

\section{Requirements for QFD Analysis}

In order to be able to define requirements and responsibilities, the customer requirements for the products must first be translated into technical characteristics. A comprehensive system for quality planning is Quality Function Deployment. QFD, approach to the department of quality functions for products from customer requirements. ASI -American Supplier Institute proposes a four-phase approach.

1. Product Planning

2. Part Planning

3. Process Planning

4. Production Planning

\begin{tabular}{|c|c|c|}
\hline input variables & phases & outputs \\
\hline $\begin{array}{l}\text { Customer } \\
\text { requirements, } \\
\text { Quality } \\
\text { requirements of } \\
\text { customers and the } \\
\text { market }\end{array}$ & $\begin{array}{l}\text { 1.Produktplanung } \\
\text { Capture customer requirements and derive } \\
\text { solution-neutral quality requirements for the } \\
\text { design }\end{array}$ & $\begin{array}{l}\text { design requirements } \\
\text { Characteristics of the products }\end{array}$ \\
\hline $\begin{array}{l}\text { Characteristics of } \\
\text { the products }\end{array}$ & $\begin{array}{l}\text { Part planning } \\
\text { Quality requirements and the design become } \\
\text { quality requirements for part system and } \\
\text { components }\end{array}$ & Features of the parts \\
\hline Features of the parts & $\begin{array}{l}\text { process planning } \\
\text { Quality requirements for the parts are } \\
\text { selected for production processes and defined } \\
\text { with process parameters }\end{array}$ & Characteristics of the processes \\
\hline $\begin{array}{l}\text { Characteristics of } \\
\text { the processes }\end{array}$ & $\begin{array}{l}\text { production planning } \\
\text { Quality assurance measures are derived from } \\
\text { the production processes and the parameters } \\
\text { of the measures are determined. }\end{array}$ & $\begin{array}{l}\text { Characteristics of the instrument } \\
\text { of production working and } \\
\text { testing instructions }\end{array}$ \\
\hline
\end{tabular}

Table 2. QFD in four phases ${ }^{\mathrm{xxi}}$ 

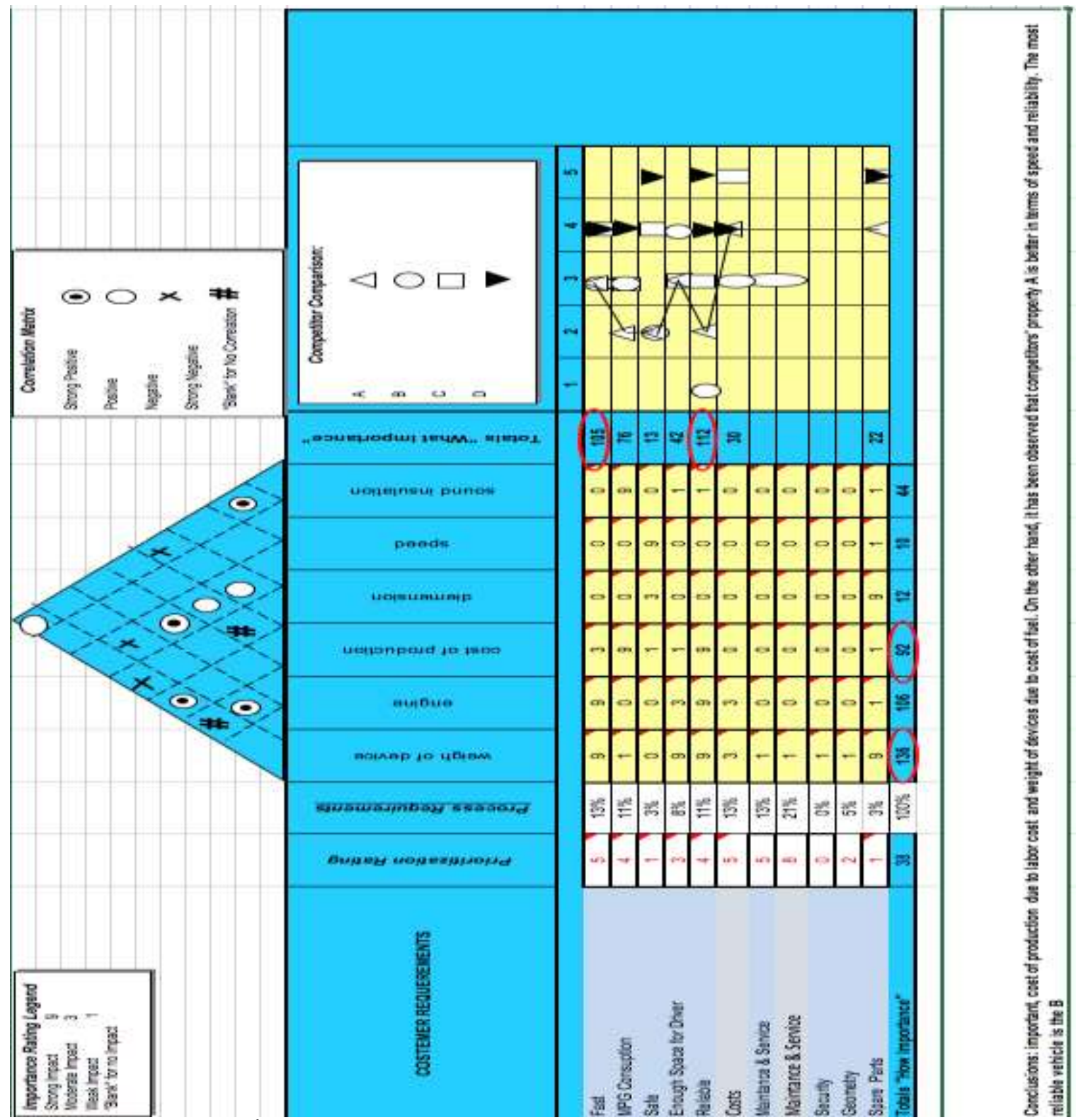

Ford Truck case study, İnönü/Turkey

\section{Conclusion}

This paper illustrates how quality function deployment has been developed as a bestPractice and a strategyprocess, its application in a variety of company. QFD method meets all requirements for effective material selection and mechanical design by using QFD method. Also, this method considering the correlation between variable of the design function.House of quality offerssome advantages compared to other existing methods. QFD is not a method for finding an optimal design algorithmically. QFD approach helps a company to evaluate product features, besides it also helps a customer to compare the product with that of other competing companies. The goal is to get hierarchical framework and to help goal programming model, by this way, gathering detailed information among the customer. This is one of the topics that should be given more attention.

One hand, this model has been served the effectiveness and efficiency of QFD and understand thevoice of customer into design and production phase and on the other hand help us most important customer requirement through decision making mode development. This model also is an approach to decision on the selection of design needs. From the case studies, it was provided the QFD that is applicable to any later stage of assembled product design.

${ }^{\mathrm{i}}$ U. Rembold, M. Seth, And J. S. Weinstein, Manufacturing Engineering and Materials Processing, Assembly Automation and Product Design Second Edition (2000), Taylor\&Franchis

ii Akao, Y. (Ed.), QFD: Integrating Customer Requirements into Product Design, Productivity Press, Cambridge, MA, Norwalk, CT, 1990. 
${ }^{\text {iii }}$ Lam K, Zhao X. An application of quality function deployment to improve the quality of teaching. International Journal of Quality \& Reliability Management, Vol. 15 Issue: 4, pp.389-413, 2006

${ }^{\text {iv }}$ Akao, Y. (Ed.), QFD: Integrating Customer Requirements into Product Design, Productivity Press, Cambridge, MA, Norwalk, CT, 1990.

'Vasilash, G., "Hearing the Voice of the Customer", Production, Vol. 101 No. 2, 1989, pp. 66-8.

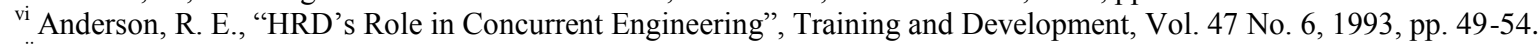

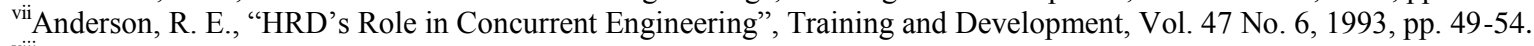

viii Ettlie, J.E., "Revisiting the 'House of Quality' Foundation”, Production, Vol. 105 No. 4, p. 26.

${ }^{\text {ix }}$ Anonymous, Machine Design, Vol. 65 No. 11, 1993, pp. 18-19.

${ }^{x}$ Yunus Kathawala, Jaideep Motwani, Implementing Quality Function Deployment: A Systems Approach, The TQM Magazine, Vol. 6 Issue: 6 , pp.31-37,

${ }^{x i}$ Catherine P. Killen, Mike Walker, Robert A. Hunt, International Journal of Quality \& Reliability Management Strategic planning using QFD, Emerald Insight, 2005

${ }^{x i i}$ Havener, C.L., "Improving the Quality of Quality", Quality Progress, Vol. 26 No. 11, 1993, pp. 41-4.

xiii Hequet, M., "Management of Technology", Training, Vol. 28 No. 4, 1991, pp. 61-5.

${ }^{\text {xiv }}$ Zairi Mohammed, Quality function deployment, A main pillar for successful total quality management and product development, International Journal of Quality \& Reliability Management, International Journal of Quality \& Reliability Management, Vol. 12 Issue: 6, pp.9-23, 1995

${ }^{\mathrm{xv}}$ Zairi Mohammed, Quality function deployment, A main pillar for successful total quality management and product development, International Journal of Quality \& Reliability Management, International Journal of Quality \& Reliability Management, Vol. 12 Issue: 6, pp.9-23, 1995

${ }^{x v i}$ Ahmed Mansour Mohsin, Karen Trimmer. Meeting the Cultural and Service Needs of Arabic International Students by Using QFD 1-22.

${ }^{x v i i}$ Mohamed Zairi, Quality function deployment, A main pillar for successful totalquality management and product development, International Journal of Quality \& Reliability Management, 1995

xviii Gausing Oliver, Fahrzeguentwicklung im Automobilbau, Hanser 2010 pp.78-88

${ }^{x i x}$ Reddy, J.N., “A Customer Driven Reliability and Quality Methodology for ExistingProducts”, SAE Technical Paper Series,27 February3 March 1989, pp. 1-9.

${ }^{x x}$ Jones, K., "High Performance Manufacturing (Part 4): A Break with Tradition”, IndustrialManagement, Vol. 12 No. 4, 1988, pp.30-2.

${ }^{x \times i}$ Condrad, K.J. Grundlagen der Konstruktionslehre. Carl Hanser Verlag. Auflage, Münschen (2009)

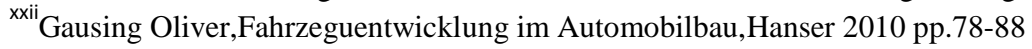

